\section{Evaluating the Market Potential for Sweetpotato Production in Southeastern Missouri}

\author{
Wesseh J. Wollo 1 \\ Cooperative Research, Lincoln University, Jefferson City, MO 65102-0029
}

Additional index words. market window, Ipomoea batatas

\begin{abstract}
A market window technique was used to evaluate the market potential for sweetpotato [Ipomoea batatas (L.) Lam.] production in southeastern Missouri. Weekly prices were averaged over 5 years in real terms and were used to identify market windows in St. Louis and Chicago. The results indicate that sweetpotatoes may be a profitable production alternative in southeastern Missouri.
\end{abstract}

Since the farm crisis of the 1980 s, producers in Missouri and other states have been encouraged to seek profitable crops as alternatives to the traditional crops, such as soybeans (Glycine max L.), wheat (Triticum aestivum L.), and corn (Zea mays L.). Because vegetables have the potential for high returns per hectare, they have been suggested as an alternative that could raise farm income, increase the use of farm labor, and create additional opportunities for small farms and farmers (Muhm, 1983). Missouri, like most midwestern states, is a major producer of the traditional crops. Currently, there is little vegetable production in the state; most vegetables sold in the state come from other regions. However, vegetable field trials by horticulturists at Lincoln Univ. suggest potential for increased yield for some of these vegetables in Missouri (Dyremple Marsh, personal communication). One such vegetable is sweetpotato, which can be produced in southeastern Missouri.

Besides considering yield potential, planning for commercial production depends on production costs (including marketing costs), expected market price, and market outlets where the produce can be sold. The purpose of this paper is to address these factors in evaluating the market potential of producing sweetpotatoes in southeastern Missouri.

\section{Materials and Methods}

The market potential for commercial sweetpotato production in southeastern Missouri was identified based on procedures that are defined generally as market window analysis. This approach is used to identify a period during which new or expanded production can be profitably marketed in a given marketplace. Although differences exist in the application of the market window approach, the tech-

Received for publication 30 July 1994. Accepted for publication 27 Sept. 1994. Research conducted at Lincoln Univ., Jefferson City, Mo. The cost of publishing this paper was defrayed in part by the payment of page charges. Under postal regulations, this paper therefore must be hereby marked advertisement solely to indicate this fact.

${ }^{1}$ Assistant Professor. niques are essentially similar (Adrian et al., 1989; Mizelle, 1983; Mook, 1985; Rahmani et al., 1990; Zwingli et al., 1987). The approach is used to analyze wholesale market price data with respect to estimated production and marketing costs. In this paper, a market window is defined as the period during which the average real price of sweetpotatoes is above the costs of production and marketing. Production and marketing cost data used in this study are estimates obtained from C.D. DeCouley (unpublished) and Schatzer et al. (1986), because information on costs of producing and marketing sweetpotatoes in southeastern Missouri is not available. The cost data are for 1990 and are recorded on an annual basis. This approach assumes that production costs are constant throughout the entire season. Production costs were calculated based on an estimated yield level of $16,800 \mathrm{~kg} \cdot \mathrm{ha}^{-1}$ (C.D. DeCouley, unpublished). Production costs include marketing and transportation costs, but not storage cost, because limited-resource farmers do not have facilities to store sweetpotatoes for a long enough time. Transportation costs were obtained from truck carriers in southeastern Missouri.

Outlets available to sweetpotato producers in southeastern Missouri include the St. Louis and Chicago terminal markets.

Price expectation is an essential factor in planning for production. Producers often form their price expectations naively based on prices received the previous year or the fresh-market price just before the planting season (Collette et al., 1978). In this paper, weekly wholesale prices of sweetpotatoes obtained over 5 years are averaged to reflect price expectations and compared to estimated costs of production and marketing. For each market, the selling price was discounted by $15 \%$ to adjust for wholesale commissions and terminal market charges (Zwingli et al., 1987). These prices were obtained from the Chicago Fresh Fruit and Vegetable Wholesale Market Prices at Chicago and the St. Louis Fresh Fruit and Vegetable Wholesale Market Prices at St. Louis publications for 1986 through 1991, published by the U.S. Dept. of Agriculture, Agricultural Marketing Service. The weekly prices for each year were deflated by the wholesale price index, with 1982 being the base period to reflect a long-run view, since conditions in the fresh vegetable market are unpredictable and volatile. These conditions may result in losses being realized in any given year; however, succeeding good years may provide profits that are sufficient to offset these losses (Love et al., 1985; Rahmani et al., 1990).

The effect on market price of an increase in quantity supplied is not addressed in this paper; any increase in quantity supplied will result in a downward pressure on price.

\section{Results}

"Market period" applies to the time of the year that sweetpotatoes produced in southeastern Missouri can be marketed. The market period for sweetpotatoes in Missouri is 26 weeks, from 23 Sept. to 15 Mar. However, because limited-resource farmers do not have facilities to store sweetpotatoes for a long enough time, the market period for them is 15 weeks, from 23 Sept. to 31 Dec.

St. Louis. In the St. Louis market, market window can be identified for 8 weeks, from week 38 to week 39 and from week 47 to week 52 (Fig. 1A). During these weeks, the average real price is above the production costs of $\$ 0.37 / \mathrm{kg}$. The mean of the average weekly prices in real terms over the market period is $\$ 0.40 / \mathrm{kg}$. This value indicates the upper limit for cost levels that will allow for profitable production of sweetpotatoes. Thus, only growers in southeastern Missouri who can produce below $\$ 0.40 / \mathrm{kg}$ can expect to make a profit, assuming that price flexibility is such that increase in quantity supplied into this market does not lead to a significant reduction in price.

Chicago. In the Chicago market, a market window can be identified for 15 weeks, from week 38 to week 52 (Fig. 1B). During this period, the average weekly real price is above the production costs of $\$ 0.40 / \mathrm{kg}$. The mean of the average weekly prices in real terms over the market period is $\$ 0.48 / \mathrm{kg}$. This value indicates the upper limit for cost levels that will allow for profitable production of sweetpotatoes for the Chicago market. Thus, only growers in southeastern Missouri who can produce below $\$ 0.48 / \mathrm{kg}$ can expect to make a profit in the Chicago market, with similar constraints as for the St. Louis market.

\section{Discussion}

Because sweetpotato production requires a larger capital investment than most other vegetable crops (Zwingli et al., 1987), knowledge of production costs is essential in evaluating the market potential of sweetpotatoes. Thus, it is important that realistic estimates are obtained. However, based on the information in Fig. $1 \mathrm{~A}$ and B, it appears that a sweetpotato producer in southeastern Missouri must produce below $\$ 0.40 / \mathrm{kg}$ to be profitable in the $S t$. Louis market, and $\$ 0.48 / \mathrm{kg}$ in the Chicago market.

For producers in southeastern Missouri with limited resources, sweetpotato produc- 


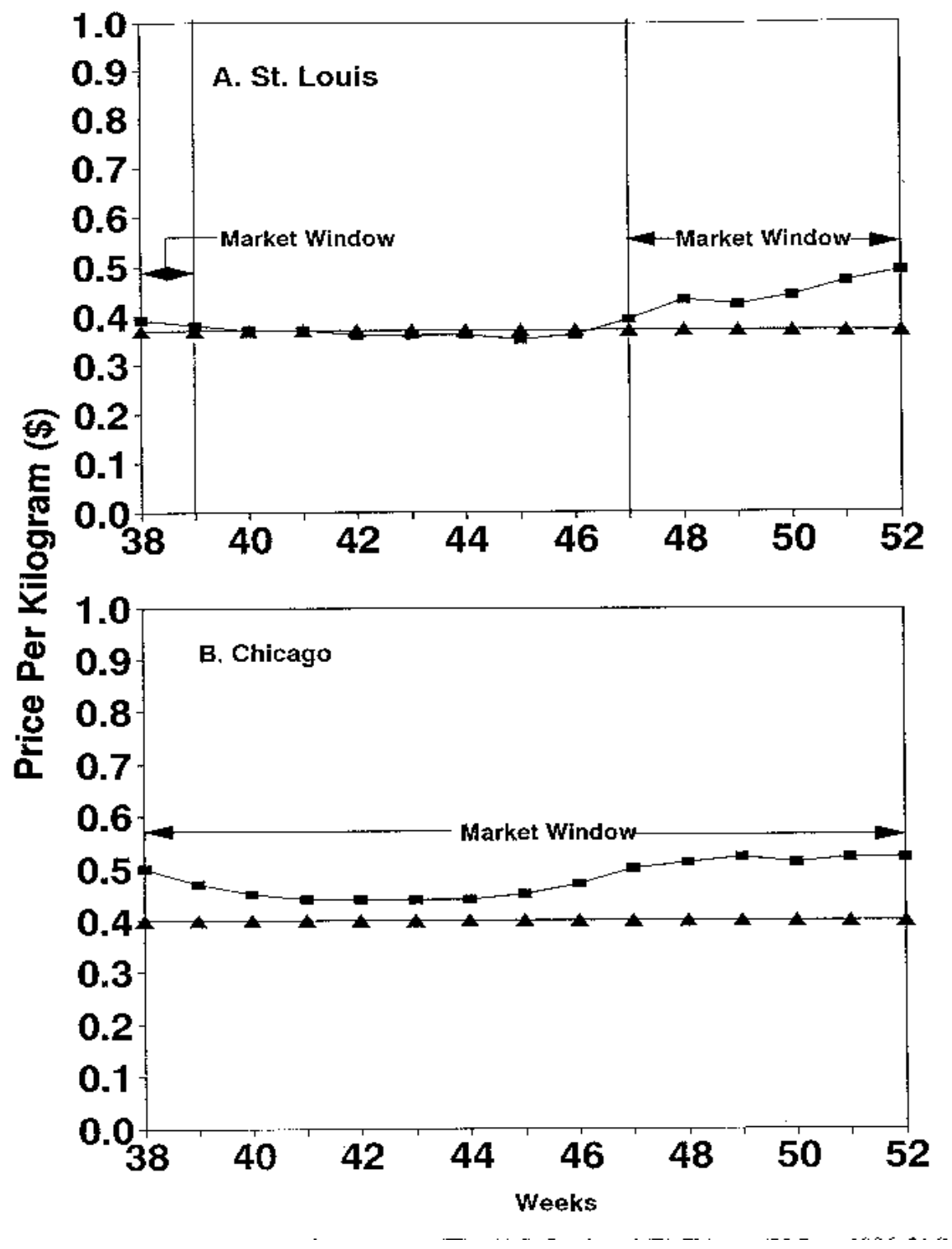

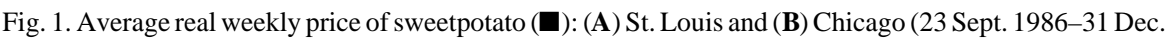
1990). Prices are adjusted $15 \%$ to reflect wholesale commission and terminal charges. Production costs $(\boldsymbol{\Delta})$ and price are expressed in dollar per kilogram. tion may be a profitable production alternative. However, if producers in this area want to take advantage of the market potential in these metropolitan areas, they must understand marketing activities associated with fresh sweetpotato production. Also, they would have to meet purchasers' volume requirements and specifications by producing sweetpotatoes in sufficient quantity and of desirable quality.

\section{Literature Cited}

Adrian, J., C. Upshaw, and R. Mook. 1989. Evaluation of feasibility of fruit and vegetable crops using market window analysis. J. Food Distribution Res., February, p. 142-152.

Collette, W.A and G.B. Wall. 1987. Evaluating vegetable production for market windows as an alternative for limited resource farmers. Southern J. Agr. Econ. 10(2):189-193.

Love, H.G., A. Hermolowicz, and F.E. Stegelin. 1985. Options for Kentucky farmers. Dept. of Agr. Econ. Publ., Univ. of Kentucky, Lexington.

Mizelle, W.O. 1983. Market windows for selected Georgia vegetables. Univ. of Georgia Coop. Ext. Serv. Bul. 887.

Mook, R.G. 1985. Applications of market window analysis: An example. Proceedings of Analyzing the Potential for Alternative Fruit and Vegetable Crop Production Seminar, New Orleans, La., 4 Nov., p. 82-93.

Muhm, D. 1983. Panels asks more diversity in farm crops. The Des Moines Register, Des Moines, Iowa, 29 June 1983. 135:5s.

Rahmani, M., T.G. Taylor, and D. Mulkey. 1990. An application of market window analysis: The case of vegetables grown on reclaimed phosphatic clay in Florida. Agribusiness 6(3):255267.

Schatzer, R.J., M.C. Wickwire, D.S. Tilley, and J.E. Motes. 1986. Costs and returns for selected fresh market vegetables in Oklahoma for small scale producers. Oklahoma Agr. Expt. Sta. Res. Rpt. P-875.

Zwingli, M.E., J.L. Adrian, W.E. Hardy, and W.J. Free. 1987. Wholesale market potential for fresh vegetables grown in North Alabama. Alabama Agr. Expt. Sta. Res. Bul. 586. 